\title{
Bibliography
}

\section{Primary Sources and Translations}

'Abd al-Razzāq b. Hammām. Mușannaf. 12 vols. Beirut: Dār al-Kutub al-'llmiyya, 2000.

Abū Dāwūd Sulaymān Ibn al-Ash'ath. Sunan. Riyadh: Maktab al-Ma'ārif lil-Nashr, 1996.

Aetius of Amida. The Gynaecology and Obstetrics of the VI century, tr. James Ricci.

Philadelphia: Blakiston, 1950.

Alif Layla or Book of the Thousand Nights and One Night, ed. W. H. Macnaghten, 4 vols.

Calcutta, 1839. English Translation: Richard Burton. The Book of a Thousand Nights and

a Night, 10 vols. Benares: Kamashastra Society, 1885.

al-Anșārī, Zakarīyā ibn Muḥammad. Asnā al-mațālib fĩ sharh Rawḍ al-țālib. 9 vols. Beirut: Dār al-Kutub al-'Ilmiyya, 2000.

Arberry, A. J. The Koran Interpreted. London: Allen \& Unwin, 1955.

Aristotle. Generation of Animals. Tr. A.L. Peck. Cambridge: Loeb Series, Harvard University Press, 1943.

Aristotle. History of Animals Vol VII-X. Tr. D. M. Balme. Cambridge: Loeb Series, Harvard University Press, 1991.

al-‘Aț̣ār, Abū'l-Munā al-Mūhīn. Minhāj al-dukkān wa-dustūr al-ayān. Beirut: Dār al-Manāhil, 1992.

al-'Ayntābī, Maḥmūd b. Aḥmad. al-Qawl al-sadīd fĩ ikhtiyār al-imā' wa'l-äbīd. Beirut:

Mu'assasat al-Risāla, 1996.

al-'Aẓīmābādī, Muḥammad Shams al-Ḥaqq. 'Awn al-ma'būd sharḥ Sunan Abī Dāwūd. 2 vols.

Beirut: Dār Ibn Ḥazm, 2005.

al-Baghdādī, 'Abd al-Lațîf. Kitāb al-Ifāda wa'l-i'tibār. London: Allen and Unwin, 1965.

al-Baladī, Abū al-'Abbās Aḥmad ibn Muḥammad. Tadbīr al-ḥabālā wa'l-ațāl wa'l-ṣibyān.

Beirut: Dār al-Kutub al-'Ilmiyya, 2004.

al-Bayhaqī, Aḥmad b. al-Ḥusayn. al-Sunan al-kubrā. Beirut: Dār al-Kutub al-‘llmiyya, 2003.

al-Bayhaqī, Aḥmad b. al-Ḥusayn. Manāqib al-Shāfi î. 2 vols. Cairo: Maktabat Dār al-Turāth, 1971.

al-Biqā‘ī, Burhān al-Dīn Ibrāhīm. Ị̇hār al-'așr li-asrār ahl al-'așr, 3 vols. Riyadh: n.p., 1993.

al-Buhūtī, Manșūr b. Yūnus. Kashshāf al-qinā’. 6 vols. Beirut: Dār al-Fikr, 1982.

al-Buhūtī, Manșūr b. Yūnus. Sharh muntahā al-irādāt. 3 vols. Beirut: Dār 'ālam al-Kutub, 1993

al-Bukhārī, Muḥammad ibn Ismāî̀l. Șaḥị̣ al-Bukhārī. Vaduz, Liechtenstein: Thesaurus Islamicus Foundation, 2000.

al-Dardīr, Aḥmad ibn Muhammad. Sharḥ al-kabīr 'alā Mukhtasar Khalīl in Ḥāshiyat al-Dasūqī 'alā al-Sharh al-kabīr. 4 vols. Beirut: Dār al-Fikr, n.d.

al-Dasūqī, Muḥammad ibn Ạ̣mad. Ḥāshīyat al-Dasūqĩ 'alā al-Sharḥ al-kabīr. 4 vols. Beirut: Dār al-fikr, n.d.

al-Dhahabī, Muḥammad b. Aḥmad. al-Ṭibb al-nabawī. Beirut: Dār lḥyā al-'Ulūm, 1990.

al-Dīnawarī, Abū Bakr. al-Mujālasa wa-jawāhir al-`ilm. Frankfurt am Main: Veröffentlichungen des Institutes für Geschichte der arabisch-islamischen Wissenschaften, 1986.

Dioscorides and T.A. Osbaldeston. Dioscorides De Materia Medica: a New English Translation. Johannesburg: IBIDIS, 2000.

Duran, Shimon b. Tsemah. Sefer ha-Tashbets. Lemberg: Uri Ze'ev Salat, 1891.

Ә OpenAccess. (C) 2020 Sara Verskin, published by De Gruyter. (cc) BY-NC-ND This work is licensed under the Creative Commons Attribution-NonCommercial-NoDerivatives 4.0 License.

https://doi.org/10.1515/9783110596588-017 
al-Fayyūmī, Aḥmad ibn Muḥammad. al-Miṣbāḥ al-munīr fĩ Gharīb al-Sharḥ al-kabīr. Beirut: Dār al-Kutub al-'Ilmiyyah, 1978.

Galen. De Usu Partium. Translated by Margaret Tallmadge May. On the Usefulness of the Parts. 2 vols. Ithaca: Cornell University Press, 1968.

Galen. On the Anatomy of the Uterus. Translated by Charles Mayo Goss. "On the Anatomy of the Uterus." The Anatomical Record 144 (1962): 77-83.

Galen. On Hippocrates' On the Nature of Man. tr. W. J. Lewis and J.A. Beach. https://www.ucl. ac.uk/ ucgajpd/medicina\%20antiqua/tr_GNatHom.html (accessed July 1, 2017.)

al-Ghazālī, Abū Ḥāmid. Iḥyā 'ulūm al-dīn. 5 vols. Cairo: Mu’assasat al-Ḥalabī, 1967.

al-Ghazālī, Abū Ḥāmid. al-Wasịt fĩ al-madhhab. 7 vols. Cairo: Dār al-Salām, 1997.

al-Hamadhānī, 'Abd al-Jabbār. Tathbīt dalā'il al-nubuwwa. Cairo: Dār al-Muștafā, 2006.

al-Ḥarīrī and F. Steingass. The Assemblies of al-Harīrī; Student's edition of the Arabic text;

with English notes, grammatical, critical, and historical. London: Sampson Low, Marston \& Co. 1897.

al-Ḥaṣkafī, Muḥammad ibn 'Alī. Durr al-mukhtār. In Hāshiyat Radd al-Muḥtār 'alā al-Durr almukhtār. 8 vols. Cairo: Mușțafa al-Ḥalabī, 1966.

al-Ḥațāāb, Muḥammad b. Muḥammad. Mawāhib al-jalīl. 6 vols. Beirut: Dār al-Fikr, 1992.

al-Haythamī, Nūr al-Dīn 'Alī ibn Abī Bakr. Majma' al-zawā'id. 10 vols. Beirut: Dār al-Kutub al'Ilmiyya, 2001.

Hippocrates. De Morbis Mulierum. Translated by Ann Ellis Hanson. “Hippocrates: 'Diseases of Women 1."' Signs 1 (1975): 567-584.

Hippocrates. De Virginum Morbis. Translated by Ann Ellis Hanson and Rebecca Flemming. “Hippocrates' 'Peri Partheniôn' (Diseases of Young Girls): Text and Translation.” Early Science and Medicine 3 (1998): 241-252.

Hippocrates. Genuine Works of Hippocrates. Tr. Francis Adams. London: The Sydenham Society, 1849.

Hippocrates. Hippocrates Vol. X. Tr. Paul Potter. Cambridge, MA: Harvard University Press, 2012.

Ibn 'Abd al-Ra'ūf and E. Lévi-Provençal. Trois Traités Hispaniques De Hisba: Texte Arabe. Cairo: Publications De L'institut Français D'archéologie Orientale Du Caire, 1955.

Ibn 'Abd al-Ra'ūf and Rachel Arié. "Traduction annotée et commentée des traités de ḥisba d'Ibn 'Abd Al-Ra'ūf et de 'Umar al-Garsîfī.” Hespéris Tamuda 1 (1960), 5-38.

Ibn 'Abdūn al-Tujibī and E. Lévi-Provençal, Séville Musulmane Au Début Du XIle Siècle: Le Traité D'ibn Abdun Sur La Vie Urbaine Et Les Corps De Métiers. Paris: G. P. Maisonneuve, 1947.

Ibn 'Ābidīn, Muḥammad Amīn b. 'Umar. Hāshiyat Radd al-Muḥtār 'alā al-Durr al-mukhtār. 8 vols. Cairo: Mușțafa al-Ḥalabī, 1966. 14 vols. Riyadh: 'Ālam al-Kutub, 2003.

Ibn Abī Shaybah, Abū Bakr 'Abdallāh b. Muḥammad. Muṣannaf fĩ al-aḥādīth wa'l-āthār. Jedda: Dār al-Qiblah lil-Nashr wa'l-Tawzī', 2006.

Ibn Abī Ușaybī'a, Ahmmad ibn al-Qāsim, 'Uyūn al-anbā' fĩ țabaqāt al-ațibbā'. Beirut: Dār Maktabat al-Ḥayāt, 1965. Partial English translation available online: L. Kopf. Lives of the Physicians. http://www.tertullian.org/fathers/ibn_abi_usaibia_03.htm

Ibn Abī Zayd al-Qayrawānī, Abū Muḥammad 'Abd Allāh. al-Nawādir wa'l-ziyādāt 'alā mā fĩ almudawwanah min ghayrihā min al-ummahāt, ed. 'Abd al-Fattāḥ Muḥammad al-Ḥulw. 15 vols. Beirut: Dār al-Gharb al-Islāmī, 1999. 
Ibn al-'Arabī, Muḥammad ibn 'Abdallāh. Ahkām al-Qur'ān, 2 vols. Beirut: Dār al-Kutub al'Ilmiyya, 1991.

Ibn al-'Aț̣̂ār, Muḥammad ibn Aḥmad. Kitāb al-Wathā'iq wa'l-sijillāt (Formulario notarial Hispano-Arabe), ed. Ch. Gendrón and F. Corriente. Madrid: Majma‘ al-Muwaththiqīn alMajrīțī, 1983.

Ibn Bābawayh, Muhammad b. 'Alī. Man lā yahḍuruhu al-faqīh. Mashhad: al-Majma', 1988. Ibn al-Barrāj, 'Abd al-'Azīz ibn Niḥrīr. al-Muhadhdhab, 2 vols. Qom: Mū'assasat al-Nashr alIslāmī, 1986.

Ibn Bassām, Nihāya al-rutba fĩ țalab al-ḥisba. Beirut: Dār al-kutub al-'ilmiyya, 2003. Ibn Bāz, 'Abd al-‘Azīz et al. Fatāwā Islamiyya. Riyadh: Darussalam, 2001.

Ibn Ezra, Abraham. Sefer Hanisyonot $=$ The Book of Medical Experiences Attributed to Abraham Ibn Ezra: Medical Theory, Rational and Magical Therapy: A Study In Medievalism, ed. J. Leibowitz and S. Marcus. Jerusalem: Magnes Press, 1984.

Ibn Ḥabīb, 'Abd al-Mālik. Kitāb adab al-nisā' al-mawsūm bi-kitāb al-ghāya wa'l-nihāya. Paris: Dār al-Gharb al-Islāmī, 1992.

Ibn Ḥajar al-Haytamī, Ạ̣mad ibn Muḥammad. Tuḥfat al-muḥtāj fĩ sharḥ al-minhāj in Ḥawāshī al-Sharawānī wa-Ibn-Qāsim al-'Abbādī 'alā tuhfat al-muhtāj bi-sharḥ al-minhāj li-lbn Ḥajar al-Haytamī. 13 vols. Beirut: Dār lḥyā’ al-Turāth al-‘Arabī, 1988.

Ibn al-Ḥājj, Muḥammad b. Muḥammad. al-Madkhal. 4 vols. Beirut: Dār al-Kutub al-‘llmiyya, 1995.

Ibn Ḥanbal, Aḥmad. Musnad. 11 vols. Beirut: ‘Ālam al-Kutub, 1998 and Cairo: Dār al-Ma‘ārif, 1951.

Ibn Ḥanbal, Ạ̣mad. Masā’il al-Imām Aḥmad bin Ḥanbal riwāyat Isḥaq ibn Ibrāhīm ibn Hāni' al-Nayșābūrī. Beirut: al-Maktab al-Islāmī, 1979.

Ibn Ḥanbal, Ạ̣mad. Masā’il al-Imām Ạ̣mad ibn Ḥanbal wa-Isḥāq ibn Rāhwayh. 10 vols. Medina: 'Imādat al-Baḥth al-'Ilmī, 2004.

Ibn Ḥanbal, Ạ̣mad. Aḥkām al-nisā' 'an al-imām Abī 'Abdallāh Aḥmad ibn Muhammad ibn Hanbal, riwāya Abī Bakr al-Khilāl. Beirut: Mu’assasat al-Rayyān lil-Ṭibā‘a wa’l-Nashr, 2002.

Ibn Ḥazm, 'Alī ibn Aḥmad. al-Muhalla. 11 vols. Cairo: Idārat al-Ṭibā‘a al-Munīriyya, 1928 and Beirut: Maktab al-tijārī lil-tibā‘a, 1969.

Ibn Ḥibbān, Muḥammad. al-Majrūḥinn min al-muhaddithīn. Aleppo: Dār al-Wa‘y, 1975. Ibn Isḥāq, Ḥunayn. Kitāb al-mawlūdīn. Baghdad: Majma' al-Lugha al-Siryāniyya, 1978. Ibn Isḥāq al-Jundī, Khalīl. Mukhtaṣar. Cairo: Dār al-Ḥadīth, 2005.

Ibn al-Jawzī, Abū al-Faraj 'Abd al-Raḥmān ibn 'Alī. Aḥkām al-nisā'. Kuwait: Maktabat Dār lbn Qutayba, 1989.

Ibn al-Jawzī, Abū al-Faraj 'Abd al-Raḥmān ibn 'Alī. Zād al-masīr fĩ 'ilm al-tafsīr. 8 vols. Beirut: Dār al-Fikr, 1987.

Ibn al-Jazzār al-Qayrawānī. Ṭibb al-fuqarā' wa'l-masākīn. Tehran: Mu'assasah-'i Muțāla‘āt-i Islāmī, Dānishgāh-i Tihrān, 1996.

Ibn al-Jazzār al-Qayrawānī and Gerrit Bos. Ibn al-Jazzār on Sexual Diseases and Their Treatment: a critical edition, English translation and introduction of Book 6 of Zād almusāfir wa-qūt al-hāẹdir. London, Kegan Paul International, 1997.

Ibn Jumay'. al-Maqāla as-Ṣalāhìiya = Treatise to Șalāh ad-Dīn on the revival of the art of medicine by Ibn Jumay': edited and translated by Hartmut Fähndrich. Marburg: Kommissionsverlag F. Steiner, 1983. 
Ibn Kathīr, Ismā'īl ibn 'Umar. Tafsīr al-Qur'ān al-'aẓīm, 8 vols. Riyadh: Dār Ṭayba lil-nashr wa'l-tawzī‘, 1997.

Ibn Kathīr, Ismā'īl ibn 'Umar. Qișaș al-anbiyā'. Damascus: Dār Ibn Kathīr, 1992. Ibn Mājah, Muḥammad ibn Yazīd. Sunan. 5 vols. Riyadh: Maktab Ma'ārif lil-Nashr, 1996. Ibn Manșūr, Sa‘īd. Sunan. 3 vols. Bombay: Dār al-Salafiyya, 1982.

Ibn Muflị, Muḥammad. al-Ādāb al-shar'iyya. 3 vols. Beirut: Mu’assasat al-Risāla, 1996. Ibn al-Naqīb and Noah Keller, The Reliance of the Traveller: A Classic Manual of Islamic Sacred Law by Ahmad ibn Naqib al-Misri. Chicago: Sunna Books, 1991.

Ibn Nujaym, Zayn al-Dīn b. Ibrāhīm. Baḥr al-rā'iq sharh kanz al-daqā'iq. 9 vols. Quetta: alMaktaba al-Mājidiyya, 1983.

Ibn al-Quff, Abū al-Faraj ibn Ya'qūb. Kitāb al-'Umda fĩ al-jirāḥa. 2 vols. Hyderabad: Majlis Dā'irat al-Ma'ārif al-'Uthmāniyya, 1937.

Ibn Qayyim al-Jawziyya, Muḥammad. al-Tibyān fĩ aqsām al-Qur'ān. Cairo: n.p., 1933.

Ibn Qayyim al-Jawziyya, Muḥammad. Zād al-ma'ād fī hady khayr al-'ibād. 6 vols. Beirut: Mu'assasat al-Risāla, 1998.

Ibn Qayyim al-Jawziyya, Muḥammad. al-Ṭibb al-nabawī. Beirut: Dār al-Fikr = Dār lḥyā al-Kutub al-'Arabiyya, 1957. English translation: Medicine of the Prophet. tr. Penelope Johnstone. Cambridge: Islamic Texts Society, 1998.

Ibn al-Qiftī, 'Alī ibn Yūsuf. Inbāh al-ruwāt 'alā anbāh al-nuhạt, ed. Muḥammad Ibrāhīm. Cairo: Dār al-Kutub al-Mișriyya, 1950.

Ibn Qudāma, Muwaffaq al-Dīn 'Abd Allāh ibn Aḥmad. al-Mughnī. 10 vols. Cairo: Maktabat alQāhira, 1968.

Ibn Rushd, Muḥammad b. Aḥmad (al-jadd). al-Bayān wa'l-taḥ̣̄ill wa'l-sharḥ wa'l-tawjīh wa'lta‘lìl fĩ masā’il al-mustakhraja, ed. Muhammad Ḥajjī. 20 vols. Beirut: Dār al-Gharb alIslamī, 1984.

Ibn Rushd, Muḥammad b. Aḥmad (al-jadd). Fatāwā Ibn Rushd. 3 vols. Beirut: Dār al-Gharb alIslāmī, 1987.

Ibn Rushd, Muḥammad b. Aḥmad (Averroes). Bidāyat al-mujtahid. 2 vols. Cairo: Dār al-Salām, 1995. English translation: The Distinguished Jurist's Primer: A Translation of Bidāyat AlMujtahid, tr. Imran Ahsan Khan Nyazee. 2 vols. Reading: Garnet, 2000.

Ibn Rushd, Muḥammad b. Aḥmad (Averroes). Kulliyāt fĩ al-țibb. Morocco: Ma'had al-jinirāl Frankū, Lajnat al-Abḥāth al-'Arabīya al-Isbānīya, 1939.

Ibn Sa'd, Muḥammad. al-Ṭabaqāt al-kubrā, 8 vols in 4. Beirut: Dār lhyya’ al-Turāth al-'Arabī, 1996.

Ibn Sahl and Oliver Kahl. Sābūr Ibn Sahl's Dispensatory in the Recension of the 'Adudī Hospital. Leiden: Brill, 2009.

Ibn Sīnā. al-Qānūn fĩ al-țibb. 3 vols. Būlāq: al-Mațba‘a al-Āmira, 1878.

Ibn Sīnā. al-Shifā'. 4 vols. Cairo: al-Hay’a al-Mișrīya al-'Āmma lil-Ta’lîf, 1970.

Ibn al-Sunnī, Aḥmad b. Muḥammad. Kitāb 'amal al-yawm wa'l-layla. Beirut: Mu’assasat alKutub al-Thaqāfiyya, 1988.

Ibn Taymiyya, Taqī al-Dīn, Fatāwā al-nisā’. Cairo: Maktabat al-Qur’ān, 1987.

Ibn Taymiyya, Taqī al-Dīn. Majmū‘ fatāwā. 37 vols. Medina: Majma‘ al-Malik Fahd li-Ṭibā‘at alMuṣhaf al-Sharīf, 2004.

Ibn al-Ukhuwwa and R. Levy. The Ma'ālim al-qurba fĩ aḥkām al-ḥisba of Diyā' al-Dīn M. b. M al-Qurashī al-Shafi`ī known as ibn al-Ukhuwwa. London: Cambridge University Press, 1938. 
Ibn Ṭūlūn, Shams al-Dīn. al-Manhal al-rawī fĩ al-țibb al-nabawī. Hyderabad: Anwār al-Ma'ārif, 1987.

Ibn Zuhr, 'Abd al-Malik ibn Abī al-'Alā'. Kitāb al-taysīr. Rabat: Akādīmīyat al-Mamlaka alMaghribiyya, 1991.

Al-Jāḥiz̧. Kitāb al-Bukhalā'. English translation: The Book of Misers, tr. R. B. Serjeant. London: Garnet \& Ithaca Press, 2000.

Al-Jazarī, Muḥammad b. Ibrāhīm. Ta'rīkh ḥawādith al-zamān wa-anbā'ihi wa-wafayaāt alakābir wa'l-a'yān min abnā'ihi. 3 vols. Beirut: al-Maktaba al-‘Așriyya, 1998.

Jones, Alan. The Qur'ān. Exeter: E. J. W. Gibb Memorial Trust, 2007.

al-Kāsānī, Abū Bakr ibn Mas'ūd. Badā'i ' al-ṣanā'it' 7 vols. Beirut: Dār al-Kutub al-’llmiyya, 1986.

al-Khaț̣̂āī, Abū Sulayman. A'lām al-Ḥadīth fĩ sharḥ Șaḥị̣ al-Bukhārī. Mecca: Jāmi'at Umm al-Qurā, Ma‘had al-Buhūth al-'Ilmiyyah wa-Iḥyā’ al-Turāth al-Islāmī, Markaz Iṇyā’ alTurāth al-Islāmī, 1988.

Lemay, H. R. Women's Secrets: A Translation of Pseudo-Albertus Magnus's “De Secretis Mulierum" with Commentaries. Albany: State University of New York Press, 1992.

Lyons, M. C. and J. N. Mattock. Kitāb al-ajinna li-Buqrāț. Cambridge: Pembroke Arabic Texts, 1978.

Maimonides, Moses. Teshuvot ha-Rambam. 3 vols. Jerusalem: Mikitse Nirdamim, 1957. al-Majlisī. Biḥār al-anwār. 44 vols. Beirut: Mu’assasat al-Wafā', 1983.

al-Majūsī, 'Alī ibn al-'Abbās. al-Kāmil al-ṣinā'a fĩ al-țibb, 2 vols. Cairo: al-Mațba'ah al-Kubrā al-'Āmira, 1877.

Mālik b. Anas. al-Muwațta', ed. 'Abd al-Majīd Turkī. Beirut: Dār al-Gharb al-Islāmī, 1999.

Mannā, Ḥasan Murad. Fatāwā wa-tawjīhāt. Cairo: Dār al-Ṣafwa, 1990.

al-Marghīnānī, Maḥmūd ibn Aḥmad. Muhịț al-burhānī fĩ al-fiqh al-Nu'mānī. 9 vols. Beirut: Dār lḥyā' al-Turāth al-'Arabī, 2003.

al-Marwarrūdhī, Ḥusayn ibn Muḥammad ibn Ạ̣mad. Fatāwā al-qāẹī Ḥusayn ibn Muḥammad al-Marwarrūdhī. Amman: Dār al-Fatḥ, 2010.

al-Māwardī. Kitāb al-ḥāwī al-kabīr. 19 vols. Beirut: Dar al-Kutub al-‘llmiyya, 1999.

al-Mawșilī, 'Abdallāh b. Maḥmūd. al-Ikhtiyār li-ta'līl al-Mukhtār. 5 vols. Beirut: Dār al-Risāla al-'Ālamiyya, 2009.

Muslim ibn al-Ḥajjāj. Șaḥịh Muslim. 5 vols. Beirut: Dār lḥyā’ al-Turāth al-'Arabī, 1955.

al-Nafrāwī, Aḥmad b. Ghunaym. al-Fawākih al-dawānī. 2 vols. Cairo: Muștafā al-Bābī alḤalabī, 1955.

al-Najafī, Muḥammad Ḥasan ibn Bāqir. Jawāhir al-kalām fĩ sharh Sharā'i al-Islām, 15 vols. Beirut: Mu'assasat al-Murtaḍā al-'Ālamiyya, 1992.

al-Nasā'̄, Aḥmad ibn Shu'ayb. Sunan. Riyadh: Maktab al-Ma'ārif lil-Nashr, 1996.

Nașār, 'Allām. "Fatwā - January 19, 1952." In Fatāwā dār al-iftā' al-mișriyya. Cairo: Wizārat al-Awqāf, 1980.

al-Nawawī, Muhyīi al-Dīn. Minhāj al-țālibīn. Beirut: Dār al-Minhāj, 2005. English translation: Minhaj et Talibin: A Manual of Muhammadan Law according to the School of Shafii, tr. E. C. Howard. London: W. Thacker \& Co., 1914.

al-Nawawī, Muhyī al-Dīn. Rawḍat al-țālibīn wa-'umdat al-muftīyīn. 8 vols. Beirut: al-Maktab al-Islāmī, 1991.

Nu'mān ibn Muḥammad and A. A. Fyzee. Pillars of Islam, 2 vols. New York: Oxford University Press, 2004 
al-Nuwayrī, Shihāb al-Dīn Aḥmad ibn 'Abd al-Wahhāb. Nihāyat al-arab fĩ funūn al-adab.

Beirut: Dār al-kutub al-'ilmiyya, 2004.

Niẓām. al-Fatāwa al-hindiyya, 6 vols. Būlāq: al-Mațba‘a al-Kubrā al-Amīriyya, 1892.

Paul of Aegina and Francis Adams. The Seven Books of Paulus AEgineta. 3 vols. London: Sydenham Society, 1844.

al-Qalyūbī, Shihāb al-Dīn Aḥmad ibn Aḥmad. Qalyūbī wa-'Umayrah: hāshiyatā al-imāmayn almuḥaqqiqayn al-mudaqqiqayn al-Shaykh Shihāb al-Dīn al-Qalyūbī wa'l-Shaykh 'Umayrah 'alá Sharh Jalāl al-Dīn al-Mahallì 'alá Minhāj al-țālibīn lil-Shaykh Muhyī al-Dīn al-Nawawī fi fiqh madhhab al-Imām al-Shāfi'ti. 4 vols. Cairo: Dār lḥyā’ al-Kutub al'Arabiyyah, 1960.

al-Qarāî̄, Shihāb al-Dīn Aḥmad b. Idrīs. al-Dhakhīrah. 15 vols. Beirut: Dār al-Gharb al-Islāmī, 1994.

al-Qazwīnī, Zakarīyā ibn Muḥammad. 'Ajā'ib al-makhlūqāt wa-al-ḥayawānāt wa-gharā'ib almawjūdāt. Beirut: Mu’assasat al-A'lamī lil-Matbū'āt, 2000.

al-Qummī, 'Alī ibn Ibrāhīm. Tafsīr al-Qummī. 3 vols. Qum: Mu'assasat al-Imām al-Mahdī, 2014.

al-Qurțubī, 'Arīb ibn Sa'īd. Kitāb khalq al-janīn wa-tadbīr al-ḥabālā wa'l-mawlūdīn = La livre de la génération du foetus et le traitement des femmes enceintes et des nouveau-nés. Algiers: Librairie Ferraris, 1956.

al-Rāzī, Muḥammad ibn Zakarīyā. al-Ḥāwī fĩ al-ṭibb. Beirut: Dar al-kutub al-'ilmiyya, 2000.

al-Rāzī, Muḥammad ibn Zakarīyā. Kitāb Shukūk 'alā Jālīnūs. Tehran: Mu'assasah-'i Muṭāla'āt-i Islāmī, Dānishgāh-i Tihrān, 1993.

al-Rāzī, Muḥammad ibn Zakarīyā. Kitāb al-tajārib: ma'a dirāsa fĩ manhaj al-baḥth al-iilmī 'inda al-Rāzī. Alexandria: Dār al-Wafā’ li-Dunyā al-Ṭibā'a wa’l-Nashr, 2006.

al-Rāzī, Muḥammad ibn Zakarīyā. al-Manșūrī fĩ al-țibb. Kuwait: Ma'had al-makhṭūtāt al'arabīya, 1987.

al-Rāzī, 'Abd al-Raḥmān ibn Abī Ḥātim. Tafsīr al-Qur'ān al-'aẓim li-ibn abī Ḥātim. 8 vols. Mecca: Maktabat Nizār Muștiafā al-Bāz, 1997.

al-Saffārīnī, Muḥammad b. Aḥmad b. Sālim. Ghidhā' al-albāb li-sharḥ Manzuūmat al-ādāb. 2 vols. Beirut: Dār al-Kutub al-‘llmiyya, 1996.

Ṣā‘id ibn al-Ḥasan. At-Tašwīq aț-țibbī des Șā‘id ibn al-Ḥasan, ed. Otto Spies. Bonn: Selbstverlag des Orientalischen Seminars der Universitat Bonn, 1968.

al-Sarakhsī, Muḥammad ibn Aḥmad. al-Mabsūṭ. 30 vols. Beirut: Dār al-Kutub al-`Ilmiyya, 1993.

al-Shāfi'ī, Muḥammad ibn Idrīs. Kitāb al-umm. 8 vols. (Beirut: Dār al-Ma'rifa, 1990).

al-Shayzarī, 'Abd al-Raḥmān ibn Naṣr. Kitāb nihāyat al-rutba fi țalab al-ḥisba lil-Shayzarī. Cairo: Lajnat al-ta'liff wa'l-tarjama wa'l-nashr, 1946.

al-Shirbīnī, Muḥammad b. Aḥmad. Mughnī al-muhtāj ilā ma'rifat ma'ānī alfāẓ al-Minhāj. 6 vols. Cairo: Maṭba'at Mușțafā al-Bābī al-Ḥalabī, 1958.

al-Shirwānī, 'Abd al-Ḥamīd. Ḥawāshī tuhfat al-muhtāj bī sharh al-Minhāj. 10 vols. Cairo: Maktaba al-tijāriyya al-kubra bi-Mișr, 1938 and Beirut: Dār al-Kutub al-'Ilmiyya, 1996.

Las Siete Partidas, tr. Samuel Parsons Scott. Chicago: The Comparative Law Bureau of The American Bar Association, 1931.

Soranus, and Oswei Temkin. Soranus's Gynecology. Baltimore: Johns Hopkins University Press, 1956. 
Stephanus, and Leendert Gerrit Westerink. Commentary On Hippocrates' Aphorisms. Berlin: Akademie-Verlag, 1985.

al-Suyūțī, Jalāl al-Dīn. Kitāb al-Raḥma fĩ al-țibb wa'l-ḥikma. Beirut: Dār al-Arqam, 2011. al-Suyūțī, Mușțafā ibn Sa'd. Mațālib ūlī al-nuhā fĩ sharḥ ghāyat al-muntahā, 6 vols. Damascus: al-Maktab al-Islāmī, 1961.

al-Ṭabarānī, Aḥmad. al-Mu'jam al-kabīr. 25 vols. Cairo: Maktabat Ibn Taymiyya, 1983. al-Ṭabarānī, Aḥmad. al-Mu'jam al-awsaț. 10 vols. Cairo: Dār al-Ḥaramayn, 1995.

al-Ṭabarī, Abū Ja'far. Tārīkh al-rusul wa'l-mulūk. Leiden: Brill, 1879. English translation: Franz Rosenthal. History of al-Tabarĩ: General Introduction and From the Creation to the Flood. Albany: SUNY Press, 1989.

al-Ṭabarī, 'Alī ibn Sahl Rabbān. Firdaws al-ḥikma fĩ al-țibb. Berlin: Mațba'at Āftāb, 1928. al-Ṭahāwī, Aḥmad b. Muḥammad. Sharh ma'ānī al-āthār. 4 vols. Beirut: 'Ālam al-Kutub, 1994. al-Tíāshī, Aḥmad ibn Yūsuf. al-Shifā fĩ al-ṭibb al-musnad 'an al-sayyid al-Muștafā. Beirut: Dār al-Ma'rifa, 1988.

al-Tirmidhī, Muḥammad b. 'T̄sā. Șaḥịh al-Tîrmidhī. 13 vols. Cairo: Maṭba'ah al-Miṣriyya bi'lAzhar, 1934.

al-Ūshī, Sirāj al-Dīn Abū Muḥammad 'Alī ibn 'Uthmān, al-Fatāwā' al-Sirājiyya. Lenasia, South Africa: Dār al-'ulūm Zakariyyā, 2011.

al-Wansharīsī, Aḥmad ibn Yaḥyā. al-Mi'yār al-mu'rib wa'l-jāmi' al-mughrib 'an fatāwā ahl Ifrīqiya wa'l-Andalus wa'l-Maghrib. 13 vols. Rabat: Wizārat al-Awqāf wa'l-Shu'ūn alIslāmiyya lil-Mamlaka al-Maghribiyya, 1981.

al-Zahrāwī, Abū al-Qāsim Khalaf ibn 'Abbās and M.S. Spink and G. L. Lewis, Albucasis on Surgery and Instruments: A Definitive Edition of the Arabic Text with English Translation and Commentary. Berkeley: University of California Press, 1973.

al-Zurqāni, Muḥammad ibn 'Abd al-Bāqī. Sharḥ al-Zurqānī 'alá Mukhtaṣar Sayyidī Khalīl. Beirut: Dār al-Kutub al-'Ilmiyya, 2002.

\section{Secondary Scholarship}

Abasiattai, A. M. et al. "Vaginal Injuries During Coitus in Calabar: A 10-year Review." Nigerian Postgraduate Medical Journal 12.2 (2005): 140-4.

Abramson, Shraga. "On the Takkanah of Tuletula (Toledo) Regarding the Husband's Inheritance of his Wife's Estate.” Zion 60 (1995): 201-224.

Abu-Lughod, Lila. "A Community of Secrets: The Separate World of Bedouin Women." Signs 10 (1985): $637-659$.

Abu-Lughod, Lila. "Feminist Longings and Postcolonial Conditions." In Remaking Women, Feminism and Modernity in the Middle East, ed. L. Abu-Lughod, 3-32. Princeton: Princeton University Press, 1988.

Agrimi, Jole and Chiara Crisciani, "Savoir médical et anthropologie religieuse: Les représentations et les fonctions de la vetula (XIIle-XVe siècle).” Annales 48 (1993), $1281-308$.

Ali, Kecia. Marriage and Slavery in Early Islam. Cambridge: Harvard University Press, 2010.

Ali, Kecia. "Marriage in Classical Islamic Jurisprudence: A Survey of Doctrines." In The Islamic Marriage Contract, ed. Frank Vogel and Asifa Quraishi, 23-25. Cambridge: Harvard University Press, 2008. 
Ali, Kecia. Sexual Ethics \& Islam. Oxford: Oneworld Publications, 2006.

Alsammani, Mohamed Al-Khatim. "Imperforate Hymen Complicated with Genital Mutilation: A Case Report," Journal of Clinical Case Reports 2 (2012): 107.

Alshech, Eli. "Notions of Privacy in Classical Sunnī Islamic Thought." Ph.D. Dissertation: Princeton University, 2004.

Alshech, Eli. "Out of Sight and Therefore Out of Mind: Early Sunnī Islamic Modesty Regulations and the Creation of Spheres of Privacy." Journal of Near Eastern Studies 66 (2007): 267-90.

'Ammār, Ḥāmid. Growing up in an Egyptian village; Silwa, Province of Aswan. New York, Octagon Books, 1966.

Amster, Ellen. Medicine and the Saints. Austin: University of Texas Press, 2013.

Amundsen, Darrel W. and Carol Jean Diers. "The Age of Menopause in Medieval Europe." Human Biology 45 (1973): 605-612.

Anonymous, "Some Facts and Figures About Women's Situation In Pakistan," Manushi 12 (1982): 5.

Antoun, Richard. "On the Modesty of Women in Arab Muslim Villages: A Study in the Accommodation of Traditions." American Anthropologist 70 (1968): 671-697.

Antoun, Richard. "Social Organization and the Life Cycle in an Arab Village," Ethnology 6 (1967): 294-308.

Ashtor, Eliyahu. "The Diet of Salaried Classes in The Medieval Near East." Journal of Asian History 4 (1970): 1-24.

Azam, Hina. Sexual Violation in Islamic Law. New York: Cambridge University Press, 2015.

Barkaï, Ron. Les infortunes de Dinah, le livre de la génération: La gynécologie juive au Moyen âge. Paris: Cerf, 1991.

Baskin, Judith. "Rabbinic Reflections on the Barren Wife." Harvard Theological Review 82 (1989): 101-14.

Batten, Rosalind. "The Arabic Commentaries On The Hippocratic Aphorisms: Arabic Learned Medical Discourse On Women's Bodies (9th-15th Cent.).” Ph.D. Dissertation: University of Manchester, 2018.

Bauer, Karen. “'Traditional' Exegesis of Q. 4:34.” Comparative Islamic Studies 2 (2006): $129-142$.

Baumgarten, Elisheva. Mothers and Children: Jewish Family Life in Medieval Europe. Princeton: Princeton University Press, 2004.

Bayoumi, Abbas. "Survivances Egyptiennes." Bulletin de la Société royale de géographie d'É gypte 19 (1937): 279-287.

Behrend-Martínez, Edward. "Female Sexual Potency in a Spanish Church Court, 1673-1735." Law and History Review 24.2 (2006): 297-330.

Behrend-Martínez, Edward. Unfit for Marriage: Impotent Spouses On Trial In the Basque Region of Spain, 1650-1750. Reno: University of Nevada Press, 2007.

Berkey, Jonathan. "Circumcision Circumscribed: Female Excision and Cultural Accommodation in the Medieval near East." International Journal of Middle East Studies 28.1 (1996): $19-38$.

Boddy, Janice. Wombs and Alien Spirits: Women, Men, and the Zar Cult in Northern Sudan. Madison: University of Wisconsin Press, 1986.

Bojlén, K. and M.W. Bentzon. "The Influence of Climate and Nutrition on Age at Menarche: A Historical Review and a Modern Hypothesis." Human Biology 40 (1968): 69-85. 
Bos, Gerrit. "On Editing and Translating Medieval Hebrew Medical Texts.” Jewish Quarterly Review 89 (1998): 101-122.

Bouhdiba, Abdelwahab. La Sexualité en Islam. Paris: Presses Universitaires de France, 1975. English translation: Sexuality in Islam. London: Saqi Books, 2004.

Boylan, Michael. "The Galenic and Hippocratic Challenges to Aristotle's Conception Theory." Journal of the History of Biology 18 (1984): 83-112.

Boylan, Michael. “Galen's Conception Theory.” Journal of the History of Biology 19 (1986): 62.

Cohen, Shaye J. D. "Purity, Piety, and Polemic: Medieval Rabbinic Denunciations of "Incorrect" Purification Practices." In Women and Water: Menstruation in Jewish Life and Law, ed. R. Wasserfall, 82-100. Hanover, NH: Brandeis University Press, 1999.

Buitelaar, Marjo. "Public Baths as Private Places." In Karin Ask and Marit Tjomsland, Women and Islamization, 103-124. Oxford: Berg, 1998.

Bürgel, Johann Christoph. "Secular and Religious Features of Medieval Arabic Medicine." In Asian Medical Systems: A Comparative Study, ed. Charles Leslie, 44-62. Berkeley: University of California Press, 1976.

Caballero-Navas, Carmen. The Book of Women's Love and Jewish Medieval Medical Literature on Women = Sefer Ahavat Nashim. New York: Kegan Paul, 2004.

Canaan, Taufiq. "Unwritten Laws Affecting the Arab Woman of Palestine." Journal of the Palestine Oriental Society 11 (1931): 172-203.

Carroll, Lucy. "Life Interests and Intergenerational Transfer of Property Avoiding the Law of Succession." Islamic Law and Society 8 (2001): 245-286.

Chaudhry, Ayesha S. "Unlikely Motherhood in the Qur’ān: Oncofertility as Devotion." In Oncofertility: Reflections from the Humanities and Social Sciences, ed. T. K. Woodruff et al., 287-94. New York: Springer, 2010.

Chipman, Leigh. The World of Pharmacy and Pharmacists in Mamluk Cairo. Leiden: Brill, 2010.

Colin, Joël. L'enfant endormi dans le ventre de sa mère: étude ethnolinguistique et juridique d'une croyance au Maghreb. Perpignan: Centre d'études et de recherches juritiques sur les espaces méditerranéen et africain francophones (CERJEMAF), 1998.

Conrad, Lawrence. The Western Medical Tradition: 800 BC to AD 1800. New York: Cambridge University Press, 1995.

Coulson, Noel J. A History of Islamic Law. Edinburgh: Edinburgh University Press, 1964.

Cuffel, Alexandra. "From Practice to Polemic: Shared Saints and Festivals as 'Women's Religion' in the Medieval Mediterranean." Bulletin of the School of Oriental and African Studies 68 (2005): 401-19.

Cuffel, Alexandra. "Polemicizing Women's Bathing among Medieval and Early Modern Muslims and Christians." In The Nature and Function of Water, Baths, Bathing, and Hygiene from Antiquity through the Renaissance, ed. Cynthia Kosso and Anne Scott 171-188. Leiden: Brill, 2009.

Cuno, Kenneth M. Modernizing Marriage: Family, Ideology, and Law in Nineteenth- and Early Twentieth-Century Egypt. Syracuse: Syracuse University Press, 2015.

Darmon, Pierre. Trial by Impotence: Virility and Marriage in Pre-Revolutionary France. London: Hogarth Press, 1985.

Das, Aileen. "Galen and the Arabic traditions of Plato's Timaeus.” Ph.D. thesis: University of Warwick, 2013. 
Dean-Jones, Leslie. "Menstrual Bleeding according to the Hippocratics and Aristotle." Transactions of the American Philological Association 119 (1974): 177-191.

Dean-Jones, Leslie. Women's Bodies in Classical Greek Science. Clarendon Press: Oxford, 1994.

Delaney, Carol. The Seed and the Soil: Gender and Cosmology in Turkish Village Society. Berkeley: University of California Press, 1991.

Dols, Michael. Majnūn: the Madman in Medieval Islamic Society. New York: Oxford University Press, 1992.

Drower, E. S. "Women and Taboo in Iraq." Iraq 5 (1938): 105-117.

Edelstein, Ludwig. Ancient Medicine. Baltimore: Johns Hopkins Press, 1967.

Effah, Kofi. "A Reformulation of the Polygyny-Fertility Hypothesis." Journal of Comparative Family Studies 30 (1999): 381-408.

Elgood, Cyril. "Tibb-ul-Nabbi or Medicine of the Prophet, Being a Translation of Two Works of the Same Name. I: The Țibb-ul-Nabbi of al-Suyūțī. II: The Țibb-ul-Nabbi of Mahmud bin Mohamed al-Chaghayni, together with Introduction, Notes and a Glossary." Osiris 14 (1962): 33-192.

Fancy, Nahyan. Science and Religion in Mamluk Egypt: Ibn al-Nafīs, Pulmonary Transit, and Bodily Resurrection. London: Routledge, 2013.

Fancy, Nahyan. "Womb Heat versus Sperm Heat: Hippocrates against Galen and Ibn Sīnā in Ibn al-Nafīs's Commentaries." Oriens 45 (2017): 150-175.

Faraone, Christopher. "Magical and Medical Approaches to the Wandering Womb in the Ancient Greek World.” Classical Antiquity 30 (2011): 1-32.

Faraone, Christopher. "The Rise of the Demon Womb in Greco-Roman Antiquity." In Finding Persephone: Women's Rituals in the Ancient Mediterranean, ed. M. Parca and A. Tzanetou, 224-37. Bloomington: Indiana University Press, 2007.

Fargues, Philippe. "The Stages of the Family Life Cycle in Cairo at the End of the Reign of Muḥammad 'Alī, According to the 1848 Census." Harvard Middle Eastern and Islamic Review 5 (2000): 1-39.

Flemming, Rebecca. "The Invention of Infertility in the Classical Greek World: Medicine, Divinity, and Gender." Bulletin of the History of Medicine 87 (2013): 565-590.

Flemming, Rebecca. Medicine and the Making of Roman Women: Gender, Nature, and Authority from Celsus to Galen. New York: Oxford University Press, 2000.

Friedl, Erika. "The Dynamics of Women's Spheres of Action in Rural Iran." In Women in Middle Eastern History: Shifting Boundaries in Sex and Gender, eds N. R. Keddie and B. Baron, 195-214. New Haven: Yale University Press, 1991.

Friedl, Erika. Women of Deh Koh. London: Penguin Books, 1991.

Friedman, Mordechai. Ribui nashim be-Yisrael = Jewish Polygyny in the Middle Ages. Jerusalem: Mossad Bialik, 1986.

Gadelrab, Sherry Sayed. "Discourses on Sex Differences in Medieval Scholarly Islamic Thought." Journal of the History of Medicine and Allied Sciences 66 (2011): 40-81.

Garver, Valerie. "Childbearing and Infancy in the Carolingian World." Journal of the History of Sexuality 21 (2012): 208-244.

Giladi, Avner. Infants, Parents and Wet Nurses: Medieval Islamic Views on Breastfeeding and their Social Implications. Leiden: Brill, 1999.

Giladi, Avner. Muslim Midwives: The Craft of Birthing in the Premodern Middle East. New York: Cambridge University Press, 2015. 
Gilchrist, Roberta. Medieval Life: Archaeology and the Life Course. Woodbridge: Boydell Press, 2012.

Gilman, Sander et al. Hysteria Beyond Freud. Berkeley: University of California Press, 1993.

Goitein, S. D. Mediterranean Society. 6 vols. Berkeley: University of California Press, 1999.

Good, Mary-Jo Delvecchio. "Of Blood and Babies: The Relationship of Popular Islamic Physiology to Fertility.” Social Science \& Medicine 14 (1980): 147-156.

Graiouid, Said. "Communication and the Social Production of Space: the Hammam, the Public Sphere and Moroccan Women." Journal of North African Studies 9 (2004): $104-130$.

Granqvist, Hilma. Child Problems Among the Arabs. Helsingfors: Södorström, 1950.

Granqvist, Hilma. Marriage Conditions in a Palestinian Village. 2 vols. Helsingfors: Akademische buchhandlung, 1931-1935.

Green, Monica. "The Transmission of Ancient Theories of Female Physiology and Disease Through the Early Middle Ages.” Ph.D. Dissertation: Princeton University, 1985.

Green, Monica. Making Women's Medicine Masculine: The Rise of Male Authority in PreModern Gynaecology. Oxford: Oxford University Press, 2008.

Green, Monica. "Caring for Gendered Bodies." In Oxford Handbook of Medieval Women and Gender, ed. Judith Bennett and Ruth Mazo Karras, 345-61. Oxford: Oxford University Press, 2013.

Guo, Li. Commerce, Culture, and Community in a Red Sea Port in the Thirteenth Century. Leiden: Brill, 2004.

Guo, Li. “Tales of a Medieval Cairene Harem: Domestic Life in al-Biqā‘ī’s Autobiographical Chronicle," Mamluk Studies Review 9 (2005): 101-121.

al-Hājirī, Sārah Shāfĩ. al-Ahkām al-muttașila bi'l-'uqm wa'l-injāb wa-man' al-ḥaml fĩ al-figh al-Islāmī. Beirut: Dār al-Bashā’ir al-Islāmīya, 2013.

Hamarneh, Sami. "Origin and Functions of the Hisbah System in Islam and Its Impact on the Health Professions." Sudhoffs Archiv für Geschichte der Medizin und der Naturwissenschaften 48 (1964): 157-173.

Hansen, Nicole Bernadette. "Motherhood in the Mother of the World: Continuity and Change of Reproductive Concepts and Practices in Egypt from Ancient to Modern Times." Ph.D. dissertation: University of Chicago, 2006.

Hanson, Ann Ellis. "Continuity and Change: Three Case Studies in Hippocratic Gynecological Therapy and Theory." In Women's History and Ancient History, ed. S. Pomeroy, 73-110. Chapel Hill: University of North Carolina Press, 1991.

Hennigan, Peter. The Birth of a Legal Institution: The Formation of the Waqf in Third-Century A.H. Hanafí Legal Discourse. Leiden: Brill, 2004.

Inhorn, Marcia. Infertility and Patriarchy: The Cultural Politics of Gender and Family Life in Egypt. Philadelphia: University of Pennsylvania Press, 1996.

Inhorn, Marcia. Quest for Conception: Gender, Infertility, and Egyptian Medical Traditions. Philadelphia: University of Pennsylvania Press, 1994.

Iversen, Erik. "Papyrus Carlsberg VIII with some remarks on the Egyptian origin of some popular birth prognoses." Det. Kongelige. Danske Videnskabernes Selskab. Historiskfilologiske Meddelelser 26 (1939): 1-31.

Jauanna, Jacques. Greek Medicine from Hippocrates to Galen. Leiden: Brill, 2012.

Jaussen, Antonin. Coutumes des Arabes au pays de Moab. Paris: V. Lecoffre, 1908. 
Jennings, Ronald C. "Women in Early 17th Century Ottoman Judicial Records: The Sharia Court of Anatolian Kayseri." Journal of the Economic and Social History of the Orient 18 (1975): 53-114.

Johnston, William. "Sexually Transmitted Diseases and Demographic Change in Early Modern Japan." East Asian Science, Technology, and Medicine 30 (2009): 74-92.

Joannides, Dimitri. Esquisse de la gynécologie et de l'obstétrique chez les égyptiens et les grecs. Cairo, 1934.

Joannides, Dimitri. La gynécologie et l'obstétrique chez Avicenne (Ibn Sina) et leurs rapports avec celles des grecs. Cairo, 1938.

Joannides, Dimitri. La gynécologie et obstétrique de Paul d'Egine et son influence sur la médecine arabe. Cairo, 1940.

Joosse, Peter. The Physician as a Rebellious Intellectual: The Book of the Two Pieces of Advice or Kitāb al-Nașịhatayn by 'Abd al-Lațîf ibn Yūsuf al-Baghdādī. Frankfurt am Main: Peter Lang Edition, 2014.

Kahle, Paul. "A Gypsy Woman in Egypt in the Thirteenth Century A.D." Journal of the Gypsy Lore Society, third series, 29 (1950): 11-15.

Kan‘ān, Aḥmad Muḥammad. al-Mawsū'a al-țibbiyya al-fiqhiyya. Beirut: Dār al-Nafā’is, 2000.

Karras, Ruth Mazo. Sexuality in Medieval Europe: Doing Unto Others. New York: Routledge, 2005.

Katz, Marion Holmes. Body of the Text. Albany: SUNY Press, 2002.

Katz, Marion Holmes. "Scholarly Authority and Women's Authority in the Islamic Law of Menstrual Purity." In Gender in Judaism and Islam: Common Lives, Uncommon Heritage, ed. Firoozeh Kashani-Sabet and Beth S. Wenger, 73-104. New York: NYU Press, 2014.

Katz, Marion Holmes. Women in the Mosque: A History of Legal Thought and Social Practice. New York: Columbia University Press, 2014.

Kedar, Benjamin Z. "Jews and Samaritans in the Crusading Kingdom of Jerusalem." Tarbiz 53 (1984), 387-408.

Khan, Geoffrey. Arabic Legal and Administrative Documents in the Cambridge Genizah Collections. Cambridge: Cambridge University Press, 1993.

Khattab, Hind et al. Women, Reproduction, and Health in Rural Egypt. Cairo: American University in Cairo Press, 1999.

King, Helen. Hippocrates' Woman: Reading the Female Body in Ancient Greece. London: Routledge, 1998.

King, Helen. "Galen and the widow: towards a history of therapeutic masturbation in ancient gynaecology." EuGeStA: Journal on Gender Studies in Antiquity 1 (2011), 205-235.

Krakowski, Eve. Coming of Age in Medieval Egypt. Princeton: Princeton University Press, 2018.

Kruk, Remke. "Pregnancy and Its Social Consequences In Mediaeval And Traditional Arab Society." Quaderni Di Studi Arabi 5/6 (1987): 418-30.

Kueny, Kathryn. Conceiving Identities: Maternity in Medieval Discourse and Practice. Albany: State University of New York Press, 2013.

Kueny, Kathryn. "The Birth of Cain: Reproduction, Maternal Responsibility, and Moral Character in Early Islamic Exegesis.” History of Religions 48 (2008): 110-129.

Kulin, H. et al. "The Effect of Chronic Childhood Malnutrition on Pubertal Growth and Development." American Journal of Clinical Nutrition 36 (1982): 527-36. 
Larguèche, Dalenda. Monogamie en Islam: l'exception kairouanaise. Manouba: Centre de publication universitaire, 2011.

Lamdan, Ruth. "Child Marriage in Jewish Society in the Eastern Mediterranean during the Sixteenth Century." Mediterranean Historical Review 11 (1996): 37-59.

Lane, Edward W. An Account of the Manners and Customs of the Modern Egyptians. New York: The American University of Cairo Press, 2003.

Lane, Edward W. Arabic-English Lexicon. 8 vols. London: Williams and Norgate, 1893.

Laqueur, Thomas. Making Sex: Body and Gender from the Greeks to Freud. Cambridge: Harvard University Press, 1990.

Layish, Aharon. "The Mālikĩ Family "Waqf" according to Wills and "Waqfiyyāt." Bulletin of the School of Oriental and African Studies 46 (1983): 1-32.

Layish, Aharon. Marriage, Divorce, and Succession in the Druze Family. Leiden: Brill, 1982. Legey, Françoise. The Folklore of Morocco, tr. Lucy Hotz. London: Unwin, 1935.

Levey, Martin. "Medical Ethics of Medieval Islam with Special Reference to Al-Ruhāwīs 'Practical Ethics of the Physician'." Transactions of the American Philosophical Society 57.3 (1967): 1-100.

Lewin, Benjamin. Otsar ha-ge'onim. Jerusalem: Hebrew University, 1928.

Lewis, M., F. Shapland and R. Watts. "On the Threshold of Adulthood: A New Approach for the Use of Maturation Indicators to Assess Puberty in Adolescents from Medieval England." Journal of Human Biology 28 (2016): 48-56.

Little, Donald P. "A Fourteenth-Century Jerusalem Court Record of a Divorce Hearing: A Case Study." In Mamluks and Ottomans: Studies in Honour of Michael Winter, ed. D. J. Wasserstein and A. Ayalon, 66-85. London: Routledge, 2006.

Livingston, John W. "Science and the Occult in the Thinking of Ibn Qayyim al-Jawziyya." Journal of the American Oriental Society 112 (1992): 598-610.

Longombe, Ahuka Ona et al. "Fistula and Traumatic Genital Injury from Sexual Violence in a Conflict Setting in Eastern Congo: Case Studies." Reproductive Health Matters 16.31 (2008): 132-141.

Lutfi, Huda. "Manners and Customs of Fourteenth-Century Cairene Women: Female Anarchy versus Male Shar'i Order in Muslim Prescriptive Treatises," 99-121. In Women in Middle Eastern History, ed. Nikki Keddie and Beth Baron. New Haven: Yale University Press, 1993.

Lydon, Ghislaine and Bruce S. Hall. "Excavating Arabic Sources for the History of Slavery in Western Africa," 15-49. In African Voices on Slavery and the Slave Trade, ed. Alice Bellagamba, Sandra E. Greene, and Martin A. Klein. Cambridge: Cambridge University Press, 2016.

Maher, Vanessa. "Women and Social Change in Morocco." In Women in the Muslim World, ed. L. Beck and N. Keddie, 100-123. Cambridge: Harvard University Press, 1978.

Marcus, Abraham. The Middle East on the Eve of Modernity: Aleppo in the Eighteenth Century. New York: Columbia University Press, 1989.

Marmon, Shaun. "Domestic Slavery in the Mamluk Empire: a Preliminary Sketch." In Slavery in the Islamic Middle East, ed. Shaun Marmon, 1-24. Princeton: Markus Wiener Pub., 1999.

Mathee, Mohamed. “Women's Agency in Muslim Marriage: Fatwās from Timbuktu.” Journal for Islamic Studies 31 (2011), 75-95. 
Meacham, Tirzah. "Marriage of Minor Girls in Jewish Law: A Legal and Historical Overview." In Jewish Legal Writings by Women, ed. M. D. Halpern and Ch. Safrai, 23-37. Jerusalem: Urim Publications, 1998.

Meyerhof, Max. "La surveillance des professions médicales et paramédicales chez les Arabes.” Bulletin de l'Institut d'Égypte 26 (1944): 119-34.

Mirza, Younus. "Remembering the Umm al-Walad." In Concubines and Courtesans: Women and slavery in Islamic History, ed. M. Gordon and K.A. Hain, 297-337. Oxford: Oxford University Press, 2017.

Moors, Annaliese. "Inheritance: Contemporary Practice." In Encyclopedia of Women in the Islamic Cultures, ed. Suad Joseph, 2: 299-302. Leiden: Brill, 2003-2007.

Morsey, Soheir A. Gender, Sickness, and Healing in Rural Egypt. Boulder, CO: Westview Press, 1993.

Morsey, Soheir A. "Sex Differences and Folk Illness." In Women in the Muslim World, ed. L. Beck and N. Keddie, 599-616. Cambridge: Harvard University Press, 1978.

Motzki, Harald. "Geschlechtsreife und Legitimation zur Zeugung im frühen Islam." In Geschlechtsreife und Legitimation zur Zeugung, ed. Ernst Wilhelm Müller, 479-550. Freiburg/Munich: Karl Alber GmbH, 1985.

Muleta, M. and G. Williams. "Postcoital Injuries Treated at the Addis Ababa Fistula Hospital, 1991-97." Lancet 354(1999): 2051-2.

Musallam, Basim. "The Human Embryo in Arabic Scientific and Religious Thought." In The Human Embryo: Aristotle and the Arabic and European Traditions, ed. G. R. Dunstan, 32-46. Exeter: University of Exeter Press, 1990.

Musallam, Basim. Sex and Society in Islam: Birth Control Before the Nineteenth Century. Cambridge: Cambridge University Press, 1983.

Natvig, Richard. "Liminal Rites and Female Symbolism in the Egyptian Zar Possession Cult," Numen 35 (1988): 57-68.

Obermeyer, Carla Makhlouf. "Pluralism and Pragmatism: Knowledge and Practice of Birth in Morocco." Medical Anthropology Quarterly 14 (2000): 180-201.

O'Dowd, Michael J. The History of Medications for Women: Materia Medica Woman. New York: Parthenon Publishing Group, 2001.

Ohtoshi, Tetsuya. "The manners, customs, and mentality of pilgrims to the Egyptian city of the dead: 1100-1500 AD." Orient 29 (1993): 19-44.

Olszowy-Schlanger, Judith. Karaite Marriage Documents From the Cairo Geniza: Legal Tradition and Community Life In Mediaeval Egypt and Palestine. Leiden: Brill, 1998.

Omran, Abdel Rahim. Family Planning in the Legacy of Islam. Routledge: New York, 1992.

Parent, A. S. et. al. "The timing of normal puberty and the age limits of sexual precocity: variations around the world, secular trends, and changes after migration." Endocrine Reviews 24.5 (2003): 668-93.

Patai, Raphael. Sex and Family in the Bible and the Middle East. New York: Doubleday, 1959.

Peirce, Leslie. Morality Tales: Law and Gender in the Ottoman Court of Aintab. Berkeley: University of California Press, 2003.

Peirce, Leslie. "Seniority, Sexuality, and Social Order: the Vocabulary of Gender in Early Modern Ottoman Society." In Women in the Ottoman Empire, ed. Madeline C. Zilfi. Leiden: Brill, 1997.

Perkins, E. E. “Marriage Ceremony in Lower Egypt.” Man 32 (1932): 63-66. 
Perlmann, Moshe. "The Position of Jewish Physicians in Medieval Muslim Countries." Israel Oriental Studies 2 (1972), 315-19.

Pinheiro, Cristina Santos. "The Medical Sources in the Chapters about Sterility of Rodrigo de Castro's De universa mulierum medicina." In The Palgrave Handbook of Infertility In History: Approaches, Contexts and Perspectives, ed. Gayle Davis and Tracey Loughran. London: Palgrave Macmillan, 2017.

Pormann, Peter. The Oriental Tradition of Paul of Aegina's Pragmateia. Leiden: Brill, 2004.

Pormann, Peter. "Female Patients, Patrons and Practitioners in 10th and 11th-Century Baghdad: An Unheard Voice?" Montreal, Institute of Islamic Studies at McGill University, May 4, 2007.

Pormann, Peter. "The Art of Medicine: Female Patients and Practitioners in Medieval Islam," Lancet 373 (2009): 1598-9.

Pormann, Peter. "The Hippocratic Aphorisms in the Arabic Medical Tradition." Aspetar 2 (2013): $412-415$.

Pormann, Peter and Emilie Savage-Smith. Medieval Islamic Medicine. Washington, D.C.: Georgetown University Press, 2007.

Porter, Venetia, Liana Saif, and Emilie Savage-Smith, "Amulets, Magic, and Talismans." In Companion to Islamic Art and Architecture. Wiley-Blackwell, 2017.

Powers, David. "Women and Divorce in the Islamic West: Three Cases." Hawwa 1 (2003): $29-45$.

Prentice, S. et al. "Evidence for a Downward Secular Trend in Age of Menarche in a Rural Gambian population.” Annals of Human Biology 37 (2010): 717-721.

Preus, Anthony. "Biomedical Techniques for Influencing Human Reproduction in the Fourth Century B.C." Arethusa 8 (1975): 237-63.

Preus, Anthony. “Galen's Criticism of Aristotle's Conception Theory." Journal of the History of Biology 10 (1977): 65-85.

Qarāmī, Amāl. al-Ikhtilāf fĩ al-thaqāfa al-'arabìya al-islāmīya. Beirut: Dār al-Madār al-Islāmī, 2007.

Ragab, Ahmed. "Epistemic Authority of Women in the Medieval Middle East." Hawwa 8 (2010): 181-216.

Ragab, Ahmed. "One, Two, or Many Sexes: Sex Differentiation in Medieval Islamicate Medical Thought." Journal of the History of Sexuality 24 (2015): 428-454.

Rank, Scott. "Polygamy and Religious Polemics in the Late Ottoman Empire: Fatma Âliye and Mahmud Es'ad's Ta'addüd-i Zevcât'a Zeyl.” Cihannüma: Tarih ve Coğrafya Araştırmaları Dergisi 1/2 (2015): 61-79.

Rapoport, Yossef. "Matrimonial Gifts in Early Islamic Egypt." Islamic Law and Society 7.1 (2000): 1-36.

Rapoport, Yossef. Marriage, Money, and Divorce in Medieval Islamic Society. Cambridge: Cambridge University Press, 2005.

Rây, P. and H.N. Gupta. Caraka Samhita; A Scientific Synopsis. New Delhi: National Institute of Sciences of India, 196.

Reinert, Benedikt. Die Lehre vom tawakkul in der klassischen Sufik. Berlin: de Gruyter, 1968.

Riddle, John. Contraception and Abortion from the Ancient World to the Renaissance. Cambridge: Harvard University Press, 1992.

Riddle, John. Goddesses, Elixirs, and Witches: Plants and Sexuality throughout Human History. New York: Palgrave Macmillan, 2010. 
Ringrose, Kathryn M. The Perfect Servant: Eunuchs and the Social Construction of Gender in Byzantium. Chicago: University of Chicago Press, 2003.

Rispler-Chaim, Vardit. Islamic Medieval Ethics in the Twentieth Century. Leiden: Brill, 1993. Rispler-Chaim, Vardit. "Ḥasan Murād Mannā: Childbearing and the Rights of a Wife." Islamic Law and Society 2 (1995): $92-99$.

Rispler-Chaim, Vardit. Disability in Islamic Law. Dordrecht: Springer, 2010.

Rosenfeld, H. "Processes of Structural Change within the Arab Village Extended Family." American Anthropologist 60 (1958): 1127-1139.

Rosen, Tova and Uriah Kfir. "What Does a Father Want?: An Unpublished Poem and Its Intertexts." In Studies in Arabic and Hebrew Letters in Honor of Raymond P. Scheindlin, ed. Jonathan Decter and Michael Rand, 129-53. Piscataway, NJ: Gorgias Press, 2007.

Rosenthal, Franz. "The Defense of Medicine in the Medieval Muslim World." Bulletin of the History of Medicine 43 (1969): 519-32.

Sabra, Adam. Poverty and Charity in Medieval Islam: Mamluk Egypt, 1250-1517. Cambridge: Cambridge University Press, 2000.

Sadeghi, Behnam. The Logic of Law-Making in Islam: Women and Prayer in the Legal Tradition. Cambridge: Cambridge University Press, 2013.

Sait, Siraj and Hilary Lim. Land, Law and Islam: Property and Human Rights in the Muslim World. New York: Zed Books, 2006.

al-Sālimī, Nūr al-Dīn 'Abd Allāh ibn Ḥumayyid. Ị̇āḥ al-bayān fĩ nikāḥ al-ṣibyān: aḥkām tazwīj al-ṣighār. Beirut: al-Dār al-'Arabiyya lil-'Ulūm, 2006.

Sanders, Paula. "Gendering the Ungendered Body: Hermaphrodites in Medieval Islamic Law." In Women in Middle Eastern History: Shifting Boundaries in Sex and Gender, ed. Nikki R. Keddie and Beth Baron, 74-95. New Haven: Yale University Press, 1991.

Savage-Smith, Emilie. "The Practice of Surgery in Islamic Lands: Myth and Reality." Social History of Medicine 13 (2000): 307-321.

Savage-Smith, Emilie. "Islamic Medical Medical Manuscripts at the National Library of Medicine," Nlm.nih.gov. https://www.nlm.nih.gov/hmd/arabic/prophetic_med2.html (accessed August 21, 2018).

Sayeed, Asma. Women and the Transmission of Religious Knowledge in Islam. Cambridge: Cambridge University Press, 2013.

Schimmel, Annemarie. And Muhammad is His Messenger: The Veneration of the Prophet in Islamic Piety. Chapel Hill: University of North Carolina Press, 1985.

Scott, S. and J. Duncan. Demography and Nutrition: Evidence from Historical and Contemporary Populations. Oxford: Wilson \& Sons, 2008.

Serour, G. I. et al. "Infertility: A Health Problem in the Muslim World.” Population Sciences 10 (1991): 41-58.

Serrano, Delfina. "Legal Practice in an Andalusī-Maghribī Source from the Twelfth Century CE: The Madhāhib al-ḥukkām fī nawāzil al-aḥkām.” Islamic Law and Society 7 (2000): 187-234.

Serrano, Delfina. "Rape in Mālikī Legal Doctrine and Practice." Hawwa 5 (2007): 166 - 207

Shaham, Ron. The Expert Witness in Islamic Courts. Chicago: University of Chicago Press, 2010.

Shatzmiller, Maya. "Women and Property Rights in Al-Andalus and the Maghrib: Social Patterns and Legal Discourse." Islamic Law and Society 2 (1995), 219-57. 
Shefer-Mossensohn, Miri. Ottoman Medicine: Healing and Medical Institutions, 1500-1700. Albany: SUNY Press, 2009.

Siggel, Alfred. "Gynäkologie, Embryologie und Frauenhygiene aus dem Paradies der Weisheit über die Medizin des Abū al-Ḥasan 'Alī b. Sahl Rabbān at-Ṭabarī." Quellen und Studien zur Geschichte Naturwissenschaften und der Medizin 8 (1941): 216-272.

Sohrabvand, Farnaz et al. "Comparison of Hysterosalpingography and Avicenna's Method for Evaluation of Tubal Patency." Traditional and Integrative Medicine 1 (2016): 90-95.

Sonbol, Amira El-Azhary. "A History of Marriage Contracts in Egypt." In The Islamic Marriage Contract, ed. Frank Vogel and Asifa Quraishi, 87-122. Cambridge: Harvard University Press, 2008.

Sonbol, Amira El-Azhary. "Shari“ Court Records And Fiqh As Sources Of Women's History." Religion \& Literature 42 (2010): 229-246.

Sourdel-Thomine, J. "Ḥammām." In Encyclopaedia of Islam, $2^{\text {nd }}$ ed., ed. P. Bearman et al. Leiden: Brill, 1960.

Spectorsky, Susan. Chapters on Marriage and Divorce. Austin: University of Texas Press, 1993.

Spellberg, Denise. Politics, Gender and the Islamic Past. New York: Columbia University Press, 1994.

Spellberg, Denise. "Writing the Unwritten Life of the Islamic Eve: Menstruation and the Demonization of Motherhood." International Journal of Middle Eastern Studies 28 (1996): $305-24$.

Sprinkle, Robert. "The Missing Politics and Unsettled Science of the Trend toward Earlier Puberty." Politics and the Life Sciences 20.1 (2001): 43-66.

Steinschneider, Moritz. "Wissenschaft und Charlatanerie unter den Arabern im neunten Jahrhundert." Virchows Archiv 36 (1866): 570-86 and 37: 560-65.

Tanner, James M. Fetus Into Man: Physical Growth from Conception to Maturity. Cambridge: Harvard University Press, 1990.

Thompson, Jason. "Small Latin and Less Greek: Expurgated Passages from Edward William Lane's An Account of the Manners and Customs of the Modern Egyptians." Quaderni di Studi Arabi 1 (2006): 7-28.

Thompson, Joseph Parrish. Photographic Views of Egypt, Past and Present. Boston: J. P. Jewett, 1856.

Tillier, Mathieu. "Women before the Qāḍi under the Abbasids." Islamic Law and Society 16 (2009): 280-301.

Tobi, Yosef. "Inheritance Rights of Jewish Women and Moslem Women in Yemen." Proceedings of the Seminar for Arabian Studies 24 (1994): 201-208.

Totelin, Laurence. Hippocratic Recipes: Oral and Written Transmission of Pharmacological Knowledge in Fifth- and Fourth-century Greece. Boston: Brill, 2008.

Tritton, A. S. Caliphs and their Non-Muslim Subjects. London: F. Cass, 1970.

Tucker, Judith E. "Muftīs and Matrimony: Islamic Law and Gender in Ottoman Syria and Palestine." Islamic Law and Society 1.3 (1994): 265-300.

Tucker, Judith E. In the House of the Law: Gender and Islamic Law in Ottoman Syria and Palestine. Berkeley: University of California Press, 2003.

Ullmann, Manfred. Die Medizin im Islam. Leiden: Brill, 1970.

Ullmann, Manfred. "Zwei spätantike Kommentare zu der hippokratischen Schrift 'De morbis muliebribus.” Medizinhistorisches Journal 12 (1977): 245-262. 
Ullmann, Manfred. Islamic Medicine. Edinburgh: Edinburgh University Press, 1978.

van de Walle, Etienne et al. Regulating Menstruation: beliefs, practices, interpretations.

Chicago, University of Chicago Press, 2001.

van der Eijk, Philip J. Diocles of Carystus. Leiden: Brill, 2001.

Verskin, Alan. "A Muslim-Jewish Friendship in the Medieval Mediterranean: 'Alī lbn al-Qifți’s Biography of Rabbi Yūsuf Ibn Sham ūn." In The Idea of the Mediterranean, ed. Mario Mignone, 184-199. Stony Brook: Forum Italicum Publishing, 2017.

Wall, L. L. "Dead Mothers and Injured Wives: The Social Context of Maternal Morbidity and Mortality among the Hausa of Northern Nigeria." Studies in Family Planning 29 (1998): 341-59.

Weisser, Ursula. Zeugung, Vererbung, und pränatale Entwicklung in der arabisch-islamischen Mittelalters. Erlangen: Hannelore Lüling, 1983.

Vieille, Paul. "Family Alliance and Sexual Politics." In Women in the Muslim World, ed. Lois Beck and Nikki Keddie, 451-472. Cambridge, Mass: Harvard University Press, 1978.

Vom Bruck, Gabriele. "Elusive Bodies: The Politics of Aesthetics among Yemeni Elite Women." Signs 23 (1997): 175-214.

Weinstein, Roni "Impotence and the Preservation of the Family in the Jewish Community of Italy in the Early Modern Period" (Hebrew). In Sexuality and the Family in History = Eros, erusin, ve-isurim: miniyut u-mishpachah ba-historiyah, ed. I. Bartal and I. Gafni Jerusalem: Merkaz Zalman Shazar le-toldot Yisrael, 1998.

Weitz, Lev. "Syriac Christians in the Medieval Islamic World: Law, Family, and Society," Ph.D. Dissertation: Princeton University, 2013.

Westermarck, Edward. Ritual and Belief in Morocco. 2 vols. London: Macmillan, 1926.

Westreich, E. "Infertility as Ground for Polygamy in Jewish Law in Italy: Interaction among Legal Traditions at the time of the Renaissance." Olir - Osservatorio delle libertà ed istituzioni religiose 2 (2003): 1-28.

Wizārat al-Awqāf wa'l-Shu'ūn al-Islāmiyya, Dawlat al-Kuwayt. al-Mawsū'a al-fiqhiyya. 45 vols. Kuwait: Wizārat al-Awqāf wa'l-Shu'ūn al-Islāmiyya, 2004.

Yazbak, Mahmoud. "Minor Marriages and Khiyār al-Bulūgh in Ottoman Palestine: A Note on Women's Strategies in a Patriarchal Society." Islamic Law and Society 9.3 (2002): $386-409$.

Zacharias, L. and R. Wurtman. "Age at Menarche: Genetic and Environmental Influences." New England Journal of Medicine 280 (1969): 868-75.

Zarinebaf-Shahr, Fariba. "Women, Law, and Imperial Justice in Ottoman Istanbul in the Late Seventeenth Century." In Women, the Family, and Divorce Laws in Islamic History, ed. Amira El Azhary Sonbol, 81-95. Syracuse: Syracuse University Press, 1996.

Zaydān, 'Abd al-Karīm. al-Mufașṣal fĩ aḥkām al-mar'a wa'l-bayt al-Muslim fĩ al-sharī'a alIslāmiyya. 11 vols. Beirut: Mu'assasat al-Risāla, 1994.

Zilfi, Madeline C. Women and Slavery in the Late Ottoman Empire: The Design of Difference. New York: Cambridge University Press, 2010. 